\title{
PENGARUH RASIO LIKUIDITAS, SOLVABILITAS, AKTIVITAS, PROFITABILITAS DAN PRODUK DOMESTIK BRUTO TERHADAP PERTUMBUHAN LABA PADA PERUSAHAAN TEKSTIL DAN GARMEN YANG TERDAFTAR DI BEI
}

\author{
Justina Trirahaju L. \\ (justin3r@gmail.com)
}

\begin{abstract}
This research is a quantitative research that aims to analyze factors influencing the profit growth at textile and garmen company listed in Indonesia Stock Exchange, that are liquidity ratio that measured by current asset, solvability ratio that measured by DER, activity ratio that measured by TATO, profitability ratio that measured by NPM and Gross Domestic Product. Population in this research is all of textile and garmen companies that listing in BEI. Implementing the purposive sampling so got 13 researches that analyzed by panel data regression with Ordinary Least Square (OLS) model. The result shows that liquidity ratio influences positively towards profit growth, solvability ratio doesn't influence towards profit growth, activity ratio doesn't influence towards profit growth, profitability ratio influences positively towards profit growth, and gross domestic product doesn't influence towards profit growth at textile and garmen companies listed in Indonesia Stock Exchange.

Based on the analysis in this study, the following suggestions are presented: (1) For further research may add other independent variables that predict the effect on profit growth and increase the number of observations in order to get better a study and research users can obtain more information, to increase the number of observation studies, the researchers can then immediately take the primary data to each company so that the collected data would be coming more and research results would be better, further research can be carried out by expanding the study area is not only the textile and garment company, but also all companies listed on the Indonesia Stock Exchange, (2) For the company to be concerned about the condition of the company's profit growth is still fluctuate every year and this proves that there is still a lack of consistency in maintaining the company's profit trend continues to rise. So it needs to be reviewed on the causes of fluctuations in profit growth
\end{abstract}

Keywords: profit growth, liquidity, solvbility, activity, profitability, GDP, OLS

\section{PENDAHULUAN}

Perusahaan tekstil dan garmen

yang merupakan perusahaan manufaktur yang sudah listing di Bursa Efek Indonesia adalah perusahaan yang sudah memiliki kategori perusahaan besar sehingga perusahaan akan memaksimalkan kemampuannya dalam menghasilkan laba. Namun demikian laba yang dihasilkan tentunya dipengaruhi oleh berbagai hal. Seperti halnya aktivitas aset yang terjadi dalam sebuah perusahaan memiliki pengaruh yang cukup besar dalam menentukan seberapa besar laba yang akan diperoleh perusahaan.

Dalam teori ekonomi, para ekonom mengartikan laba sebagai suatu kenaikan dalam kekayaan perusahaan, sedangkan dalam akuntansi, laba adalah perbedaan pendapatan yang direalisasi dari transaksi yang terjadi pada waktu 
dibandingkan dengan biaya-biaya yang dikeluarkan pada periode tertentu (Harahap 1997). Pertumbuhan laba merupakan kenaikan atau penurunan laba per tahun. Pertumbuhan laba yang tinggi mengindikasikan laba yang diperoleh perusahaan tinggi, sehingga tingkat pembagian deviden perusahaan tinggi pula. Maka dari itu, Pertumbuhan laba akan mempengaruhi keputusan investasi para investor yang akan menanamkan modalnya ke dalam perusahaan. Hal ini dikarenakan investor mengharapkan dana yang diinvestasikan ke dalam perusahaan akan memperoleh tingkat pengembalian tinggi.

Salah satu alternatif untuk mengetahui apakah informasi keuangan yang dihasilkan dapat bermanfaat untuk memprediksi pertumbuhan laba, termasuk kondisi keuangan di masa depan adalah dengan melakukan analisis rasio keuangan. Analisis rasio keuangan berguna untuk mengindikasikan kekuatan dan kelemahan keuangan suatu perusahaan.

Rasio yang digunakan dalam penelitian ini meliputi 10 rasio yaitu current ratio, gross profit margin, operating profit margin, net profit margin, debt to equity, inventory turn over, total asset turnover, return on investment, return on equity dan leverage ratio, selain kesepuluh rasio tersebut penelitian ini juga menggunakan ukuran perusahaan. Hasil penelitian menunjukkan bahwa dari kesepuluh rasio keuangan yang digunakan hanya rasio Gross Profit Margin (GPM) dan Operating Profit Margin (OPM) yang signifikan dalam memprediksi perubahan laba yang akan datang. Selain itu, Juliana dan Sulardi juga menemukan bukti empiris bahwa rasio keuangan dan ukuran perusahaan mampu memprediksi dan berpengaruh terhadap perubahan laba perusahaan manufaktur.
Selain rasio-rasio keuangan, faktor lainnya juga diprediksi dapat mempengaruhi pertumbuhan laba yaitu Produk Domestik Bruto atau PDB yang merupakan faktor makroekonomi atau eksternal perusahaan. Meningkatnya PDB merupakan sinyal yang baik (positif) untuk investasi dan sebaliknya. Meningkatkan PDB mempunyai pengaruh positif terhadap daya beli konsumen sehingga dapat meningkatkan permintaan terhadap produk perusahaan. Adanya peningkatan permintaan terhadap produk perusahaan maka akan meningkatkan pula pertumbuhan laba perusahaan.

Berangkat dari penjelasan di atas mengenai pengaruh beberapa rasio keuangan dan kondisi makroekonomi terhadap pertumbuhan laba, mendorong penulis untuk melakukan pengujian lebih lanjut atas temuan-temuan empiris mengenai rasio keuangan, makroekonomi dan pertumbuhan laba yang akan dilakukan pada perusahaan manufaktur jenis tekstil dan garmen yang terdaftar di BEI.

\section{KERANGKA TEORITIS DAN HIPOTESIS}

Seorang investor yang rasional melakukan analisa sebelum membuat keputusan investasi. Menurut Sari dan Zuhrotun (2006), teori sinyal (signaling theory) menjelaskan mengapa perusahaan mempunyai dorongan untuk memberikan informasi laporan keuangan pada pihak eksternal. Keterkaitan antara teori sinyaling dengan penelitian ini yaitu terletak pada rasio-rasio keuangan yang merupakan indikator mikro ekonomi dan PDB yang merupakan indikator makro ekonomi menjadi sinyal-sinyal yang diprediksi berpengaruh terhadap pertumbuhan laba, sehingga investor akan menilai mengenai kinerja perusahaan dari rasio 
keuangan dan PDB sebagai faktor luar yang menjadi petunjuk naik turunnya pertumbuhan laba.

Teori keagenan (agency theory) yang dipelopori oleh Jensen \& Meckling (1976) mengatakan bahwa hubungan keagenan merupakan suatu kontrak antara satu atau lebih orang (prinsipal) yang menghendaki orang lain (manajer) untuk melaksanakan jasa dengan cara mendelegasikan wewenang pengambilan keputusan kepada agen. Teori keagenan menyatakan bahwa perusahaan yang memisahkan fungsi pengelolaan dan kepemilikan akan rentan terhadap konflik keagenan. Pada model keagenan dirancang sebuah sistem yang melibatkan kedua belah pihak yaitu manajemen dan pemilik. Selanjutnya, manajemen dan pemilik melakukan kesepakatan (kontrak) kerja untuk mencapai manfaat (utilitas) yang diharapkan. Sesuai dengan agency theory, motivasi manajemen akrual dapat dikelompokkan ke dalam dua kategori: opportunistic dan signaling (Beaver 2002). Pada motivasi opportunistic, manajemen melalui kebijakan aggressive accounting menghasilkan angka laba lebih tinggi daripada laba yang sesungguhnya. Apabila laporan laba tidak dapat menggambarkan laba yang sesungguhnya, maka laporan laba mengarah pada overstate earnings. Laba yang mengarah pada overstate earnings mengakibatkan laba menjadi kabur (opaque). Motivasi opportunistic yang dilakukan oleh manajemen berhubungan dengan kompensasi berdasarkan kontrak yang disepakati dengan pihak pemilik.

Kaitan antara teori agensi dengan penelitian ini terletak pada keberhasilan operasional manajemen dalam mengelola perusahaan sehingga dapat meningkatkan kinerja perusahaan. Rasio-rasio keuangan yang ada pada penelitian ini menjadi indikator keberhasilan manajemen sebagai agensi dalam melaksanakan perintah pemilik (prinsipal) guna mencapai tujuan akhir yaitu memperoleh laba yang tinggi dan dapat meningkatkan pertumbuhan laba dari tahun ke tahun.

Pertumbuhan laba adalah suatu kenaikan laba atau penurunan laba pertahun yang dinyatakan dalam prosentase (Irmayanti, 2011) dalam Irawati (2012). Sedangkan menurut Jang (2007) Pertumbuhan laba adalah variabel yang menjelaskan prospek pertumbuhan perusahaan pada masa mendatang. Perusahaan yang memiliki kesempatan untuk tumbuh yang lebih besar mempunyai koefisien respon laba yang tinggi.

Pengaruh Current Ratio terhadap pertumbuhan laba adalah semakin tinggi nilai Current Ratio maka laba bersih yang dihasilkan perusahaan semakin sedikit, karena rasio lancar yang tinggi menunjukkan adanya kelebihan aktiva lancar yang tidak baik terhadap profitabilitas perusahaan karena aktiva lancar menghasilkan return yang lebih rendah dibandingkan dengan aktiva tetap (Hanafi dan Halim, 2003). Nilai Current Ratio yang tinggi belum tentu baik ditinjau dari segi profitabilitasnya.

Dalam penelitian-penelitian sebelumnya ada beberapa peneliti yang menggunakan Current Ratio untuk memprediksi pertumbuhan laba yang akan datang. Hasil penelitian Asyik dan Soelistyo (2000) menguji manfaat rasio keuangan untuk memprediksi perubahan laba pada 50 perusahaan manufaktur yang terdaftar di Bursa Efek Jakarta (BEJ). Dari hasil penelitian tersebut dapat diketahui bahwa Current Ratio tidak mempunyai kemampuan signifikan dan tidak dapat dijadikan sebagai diskriminator dalam memprediksi perubahan laba. Begitu 
pun hasil penelitian Juliana dan Sulardi (2003) yang menggunakan Current Ratio untuk memprediksi perubahan laba pada perusahaan manufaktur yang terdaftar di Bursa Efek Jakarta (BEJ) dengan periode penelitian 1998-2000. Hasil penelitian menunjukkan bahwa Current Ratio tidak mempunyai kemampuan signifikan dalam memprediksi laba tetapi mempunyai hubungan yang positif dengan perubahan laba. Berbeda dengan Sari (2007:52) dalam penelitiannya menyimpulkan bahwa rasio lancar secara parsial berpengaruh positif terhadap perubahan laba.

H1: Rasio Likuiditas berpengaruh negatif terhadap pertumbuhan laba

Menurut Van Horne (2009), semakin tinggi rasio Debt to Total Asset, semakin besar risiko keuangannya. Yang dimaksudkan dengan terjadinya peningkatan risiko adalah kemungkinan terjadinya default karena perusahaan terlalu banyak melakukan pendanaan aktiva dari hutang. Dengan adanya gagal bayar, maka biaya yang harus dikeluarkan oleh perusahaan untuk mengatasi masalah ini semakin besar.

Berdasarkan Pecking Order

Theory, semakin besar rasio leverage, menunjukkan bahwa semakin besar biaya yang harus ditanggung perusahaan untuk memenuhi kewajiban yang dimilikinya. Hal ini dapat menurunkan profitabilitas yang dimiliki oleh perusahaan. Oleh karena itu, ada hubungan antara leverage dan profitabilitas (Tong dan Green 2005)

$$
\text { Menurut Weston dan }
$$

Copeland,(1989) dalam Lusiana (2008), para kreditor lebih menyukai rasio hutang yang moderat, semakin rendah rasio ini akan ada semacam perisai sehingga kerugian yang diderita semakin kecil saat dilikuidasi, sebaliknya pemilik lebih menyukai rasio hutang yang tinggi, karena leverage yang tinggi akan memperbesar laba bagi perusahaan. Hal ini berpengaruh terhadap kemampuan perusahan dalam memprediksi laba di masa depan dengan melihat resikodari keputusan yang diambil.

H2: Rasio Solvabilitas berpengaruh negatif terhadap pertumbuhan laba

Semakin tinggi rasio aktivitas semakin efisien penggunaan asset dan semakin cepat pengembalian dana dalam bentuk kas (Abdul Halim 2007). Total Assets Turn Over sendiri merupakan rasio antara penjualan dengan total aktiva yang mengukur efisiensi penggunaan aktiva secara keseluruhan. Apabila rasio rendah itu merupakan indikasi bahwa perusahaan tidak beroperasi pada volume yang memadai bagi kapasitas investasinya.

Semakin besar TATO menunjukkan perusahaan efisien dalam menggunakan seluruh aktiva perusahaan untuk menghasilkan penjualan bersihnya.Semakin cepat perputaran aktiva suatu perusahaan untuk menunjang kegiatan penjualan bersihnya, maka pendapatan yang diperoleh meningkat sehingga laba yang didapat besar (Ang 1997).

Ou (1990) menunjukkan bahwa rasio aktivitas yang berpengaruh signifikan untuk memprediksi pertumbuhan laba. Sedangkan Asyik dan Soelistyo (2000) melakukan penelitian yang menguji kemampuan rasio Total Asset Turn Over untuk memprediksi perubahan laba yang akan datang pada 50 perusahaan manufaktur yang terdaftar di Bursa Efek Jakarta (BEJ). Hasil penelitian menunjukkan bahwa rasio Total Asset Turn Over mempunyai pengaruh yang positif dan kemampuan yang signifikan dalam memprediksi perubahan laba yang akan datang. Begitu pun hasil penelitian Sari (2007) yang menyimpulkan bahwa 
TATO secara simultan berpengaruh terhadap perubahan laba, juga didukung oleh Cahyadi (2013) namun hasil penelitian Mustarsyidah (2009) menunjukkan bahwa perubahan TATO tidak berpengaruh terhadap perubahan laba di masa yang akan datang

H3: Rasio Aktivitas berpengaruh positif terhadap pertumbuhan laba.

Menurut Robert Ang (1997), Net

Profit Margin menunjukkan rasio antara laba bersih setelah pajak atau net income terhadap total penjualan. Rasio ini mengukur kemampuan perusahaan meghasilkan pendapatan bersih terhadap total penjualan yang dicapai. Sedangkan menurut Sartono (2000), NPM merupakan rasio antara EAT setelah pajak dengan penjualan, yang mengukur EAT yang dihasilkan dari setiap rupiah penjualan. Rasio ini juga dibandingkan dengan rata-rata industry. Begitu pun menurut Hanafi dan Halim (2007: 83) rasio profit margin mengukur kemampuan perusahaan menghasilkan laba bersih pada tingkat penjualan tertentu. Rasio profit yang tinggi menandakan adanya kemampuan perusahaan yang tinggi untuk menghasilkan laba bersih pada penjualan tertentu (Slamet 2003). Apabila rasio profit margin meningkat, maka pendapatan pada masa yang akan datang diharapkan meningkat, hal ini disebabkan pendapatan laba bersihnya lebih besar dari pendapatan operasionalnya sehingga kemampuan menghasilkan laba bersih meningkat yang akhirnya akan meningkatkan pendapatan.Zhang (2000) dengan profitabilitas rendah, laba yang diharapkan diterima sebelum pemberhentian adalah tidak signifikan. Sehingga perusahaan yang profitabilitasnya rendah maka pertumbuhan labanya akan menurun.

NPM yang semakin besar menunjukkan bahwa semakin besar laba bersih yang diperoleh perusahaan dari kegiatan penjualan. Dengan laba bersih yang besar, bertambah luas kesempatan bagi perusahaan untuk memperbesar modal usahanya tanpa melalui hutanghutang baru, sehingga pendapatan yang diperoleh menjadi meningkat (Reksoprayitno, 1991)

Zainuddin dan Jogiyanto (1999) dalam penelitiannya mengatakan bahwa Net Profit Margin berpengaruh positif signifikan dalam memprediksi pertumbuhan laba perusahaan perbankan untuk periode satu tahun ke depan. Hasil penelitian Takarini dan Ekawati (2003) menyimpulkan bahwa Net Profit Margin (NPM) berpengaruh positif dan signifikan terhadap perubahan laba.Hasil ini didukung oleh Asyik dan Soelistyo (2000), Juliana dan Sulardi (2003) serta Hapsari (2007).

H4: Rasio aktivitas berpengaruh positif terhadap pertumbuhan laba

Menurut pendekatan produksi, Produk Domestik Bruto (PDB) adalah jumlah nilai barang dan jasa akhir yang dihasilkan oleh berbagai unit produksi di wilayah suatu negara dalam jangka waktu setahun. Produk domestik bruto dapat pula diartikan sebagai nilai barang-barang dan jasa-jasa yang diproduksikan oleh faktor-faktor produksi milik warga negara tersebut dan negara asing dalam satu tahun tertentu.

Meningkatnya PDB merupakan sinyal yang baik (positif) untuk investasi dan sebaliknya. Meningkatkan PDB mempunyai pengaruh positif terhadap daya beli konsumen sehingga dapat meningkatkan permintaan terhadap produk perusahaan. Adanya peningkatan permintaan terhadap produk perusahaan maka akan meningkatkan pula pertumbuhan laba perusahaan.

Peningkatan PDB mencerminkan peningkatan daya beli 
konsumen di suatu negara. Adanya peningkatan daya beli konsumen menyebabkan peningkatan permintaan masyarakat terhadap barang dan jasa perusahaan yang nantinya akan meningkatkan profit perusahaan (Kewal, 2012).

H5: PDB berpengaruh positif terhadap pertumbuhan laba.

\section{METODOLOGI}

\section{A. Metode Penelitian}

Populasi dalam penelitian ini adalah seluruh perusahaan manufaktur yang bergerak di bidang tekstil dan garmen yang terdaftar di BEI, yang pada tahun 2012 sebanyak 19 perusahaan, dengan periode penelitian dari tahun 2010 sampai dengan 2012. Metode pemilihan sampel berdasarkan kriteria (purposive sampling) antara lain: Perusahaan tekstil dan garmen yang terdaftar di BEI yang menyediakan data laporan keuangan yang dipublikasikan selama periode penelitian (2010-2012), serta perusahaan tekstil dan garmen yang terdaftar di BEI yang data laporan keuangan lengkap selama periode penelitian (2010-2012).

Dalam penelitian ini mengambil objek penelitian, yaitu perusahaan tekstil dan garmen yang terdaftar di Bursa Efek Indonesia (BEI) yang memiliki laporan keuangan dan dipublikasikan.

Variabel dependen yang digunakan adalah pertumbuhan laba, variabel independen yaitu rasio likuiditas dengan current ratio (CR), rasio solvabilitas dengan Debt to Equity Ratio (DER), rasio aktivitas dengan Total Asset Turnover (TATO), Net Profit Margin (NPM), Produk Domestik Bruto (PDB)

\section{B. Teknik Analisis}

Penelitian ini menggunakan uji asumsi klasik yang meliputi : uji multikolinieritas, uji autokorelasi, uji heteroskedastisitas dan uji normalitas sebelum melakukan pengujian hipotesis dengan meggunakan analisis regresi berganda dengan persamaan kuadrat terkecil (ordinary least square-OLS) dengan model dasar sebagai berikut (Gujarati, 1995).

PertumbuhanLaba $=\mathbf{a}+\mathbf{b} 1 \mathrm{CR}+\mathrm{b} 2$ DER + b3 TATO+ b4 NPM + b5 PDB +e

\section{HASIL DAN PEMBAHASAN}

\section{A. Hasil \\ Hasil penelitian menunjukkan} nilai VIF dari masing-masing variabel independen yaitu likuiditas, DER, TATO, NIM dan PDB pada Perusahaan Tekstil dan Garmen yang Terdaftar di BEI berada di sekitar angka 1 (kurang dari angka 10). Dan nilai tolerance (TOL) yang diperoleh menunjukkan nilai lebih besar dari 0,10. Dari hasil tersebut dapat diketahui bahwa dalam model regresi terbebas dari multikolinieritas antar variabel independen.

Berdasarkan hasil analisis regresi uji autokorelasi (lihat tabel 4.4) nilai Durbin Watson (DW) sebesar 2,189. Sedangkan berdasarkan tabel Durbin Watson (DW) dengan $\mathrm{k}=5$ dan $\mathrm{n}=38$ maka nilai $\mathrm{dL}=1,204$ dan $\mathrm{dU}=1,792$, maka $4-\mathrm{dU}=2,208$ dan $4-\mathrm{dL}=$ 2,276 . Oleh karena itu nilai DW berada di antara dU dan 4-dU sehingga dapat ditarik kesimpulan tidak terjadi autokorelasi.

Dari tabel tersebut dapat diketahui bahwa nilai sig. semua variabel independen lebih dari besar dari 0,05 . Hal ini berarti tidak terjadi gejala heteroskedastisitas pada model regresi dalam penelitian ini.

Berdasarkan output di atas, dapat kita lihat bahwa nilai Asymp. Sig (2-tailed) yaitu 0,099. Nilai ini lebih besar dari 0,05 atau 5\%. Sehingga dapat 
disimpulkan bahwa data dinyatakan berdistribusi normal dan dapat dikatakan bahwa model regresi memenuhi asumsi normalitas sehingga data layak untuk digunakan.

\section{B. Pembahasan}

Analisis data yang digunakan pada penelitian ini yaitu dengan analisis data panel model Ordinary Least Square (OLS) dengan bantuan SPSS. Untuk mengetahui ketepatan model (goodness of fit) pengaruh variabel independen yaitu rasio likuiditas yang diukur dengan current ratio, rasio solvabilitas yang diukur dengan Debt to Equity Ratio (DER), rasio aktivitas yang diukur dengan Total Aset Turn Over (TATO), rasio profitabilitas yang diukur dengan Net Profit Margin (NPM) dan makroekonomi yang diukur dengan PDB terhadap variabel dependen yaitu pertumbuhan laba maka dilakukan uji F.

Tabel 1. Hasil Perhitungan Uji Ketepatan Model

\begin{tabular}{lrrrrr}
\hline Model & Sum of Squares & Df & Mean Square & F & Sig. \\
\hline 1Regression & 76.552 & 5 & 15.310 & $3.502 .012^{\mathrm{a}}$ \\
Residual & 139.915 & 32 & 4.372 & \\
Total & 216.468 & 37 & & \\
\hline
\end{tabular}

Sumber: Output SPSS (Data diolah)

Berdasarkan tabel di atas diperoleh hasil bahwa nilai Fhitung yaitu sebesar 3,502 dan dengan nilai signifkansi sebesar 0,012 atau lebih kecil dari batas nilai signifkansi $(\alpha=$ $0,05)$. Hasil penelitian ini menunjukkan bahwa dalam rangka untuk menjelaskan variabel pertumbuhan laba, maka variabel CR, DER, TATO, NPM dan PDB dapat digunakan secara bersamasama karena model sudah layak digunakan.

Selanjutnya untuk pengujian keempat hipotesis yang telah diajukan, maka dilakukan dengan menggunakan uji t. Pengujian ini dilakukan untuk mengetahui apakah variabel independen secara parsial berpengaruh secara signifikan terhadap variabel dependen. Berdasarkan hasil pengujian dengan menggunakan alat analisis regresi data panel diperoleh hasil sebagai berikut:

Tabel 2. Hasil Perhitungan Uji t

\begin{tabular}{|c|c|c|c|c|c|}
\hline \multirow[b]{2}{*}{ Model } & \multicolumn{2}{|c|}{ Unstandardized Coefficients } & \multirow{2}{*}{$\begin{array}{c}\begin{array}{c}\text { Standardized } \\
\text { Coefficients }\end{array} \\
\text { Beta }\end{array}$} & \multirow[b]{2}{*}{$\mathrm{t}$} & \multirow[b]{2}{*}{ Sig. } \\
\hline & $\mathrm{B}$ & Std. Error & & & \\
\hline 1 (Constant) & -4.645 & 18.198 & & -.255 & .800 \\
\hline $\mathrm{CR}$ & 1.103 & .538 & .330 & 2.052 & .048 \\
\hline DER & .091 & .101 & .136 & .902 & .374 \\
\hline TATO & .615 & .947 & .099 & .650 & .521 \\
\hline NPM & .598 & .248 & .390 & 2.411 & .022 \\
\hline PDB & .305 & 2.913 & .016 & .105 & .917 \\
\hline
\end{tabular}

a. Dependent Variable: Pertumbuhan Laba

Sumber: Output SPSS (data diolah) 
Berdasarkan hasil analisis pada tabel 4.8 diperoleh nilai $t$ hitung sebesar 2,052 sedangkan $\mathrm{t}$ tabel sebesar 2,024 maka $\mathrm{t}$ hitung $>\mathrm{t}_{\text {tabel }}$ sehingga Ho ditolak dan Ha diterima, atau dengan melihat tingkat signifikansi yaitu sebesar 0,048, maka likuiditas berpengaruh signifikan terhadap pertumbuhan laba pada perusahaan tekstil dan garmen yang terdaftar di BEI. Dengan demikian hipotesis pertama yang menyatakan bahwa rasio likuiditas berpengaruh negatif terhadap pertumbuhan laba ditolak.

Pada penelitian ini, hasil analisis mendukung Sari (2007) yang menyatakan bahwa likuiditas berpengaruh positif terhadap pertumbuhan laba, terbukti bahwa nilai signifikansi sebesar 0,045 , nilai ini dibawah 0,05. Sehingga hasil membuktikan ada pengaruh positif likuiditas terhadap pertumbuhan laba.Hal ini berarti current ratio yang tinggi menunjukkan kinerja keuangan yang baik karena dapat menunjukkan kemampuan perusahaan dalam melunasi hutang jangka pendeknya. Selain itu dengan likuiditas yang tinggi maka perusahaan mampu menggunakan aktiva lancarnya untuk meningkatkan kapasitas operasionalnya terutama kapasitas produksi pada perusahaan tekstil dan garmen yang nantinya akan berimbas pada perolehan laba sehingga laba yang dihasilkan akan terus meningkat.

Berdasarkan hasil analisis diperoleh nilai $\mathrm{t}$ hitung sebesar 0,902 sedangkan $t$ tabel sebesar 2,024 maka $t$ hitung $<\mathrm{t}$ tabel.dengan demikianmaka $\mathrm{Ha}$ ditolak dan Ho diterima, atau dengan melihat tingkat signifikansi yaitu sebesar 0,374, maka rasio solvabilitas tidak berpengaruh signifikan terhadap pertumbuhan laba pada perusahaan tekstil dan garmen yang terdaftar di
BEI. Dengan demikian hipotesis kedua yang menyatakan bahwa rasio solvabilitas berpengaruh negatif terhadap pertumbuhan laba tidak dapat diterima.

Penelitian ini ternyata menolak hipotesis yang telah diajukan sebelumnya yang artinya bahwa rasio solvabilitas yang diukur dengan DER tidak menunjukkan adanya pengaruh. Hal ini berarti pada perusahaan tekstil dan garmen yang terdaftar di BEI berapa pun besarnya DER atau berapa pun besarnya resiko yang dimiliki tidak akan mempengaruhi besar kecilnya pertumbuhan laba. Ini berarti hutang sudah menjadi suatu kewajiban dan hal yang lumrah terjadi pada dunia usaha, karena dengan hutang maka kebutuhan perusahaan dalam beroperasi akan terpenuhi terutama perusahaan tekstil dan garmen yang setiap hari memproduksi pakaian sehingga membutuhkan dana yang sangat besar. Hutang tentunya akan menjadi modal bagi manajemen dalam rangka meningkatkan produktivitas guna memuaskan principal, dan hal ini tidak menjadi penghalang bagi manajemen untuk menunjukkan pertumbuhan laba.

Berdasarkan hasil analisis diperoleh nilai $\mathrm{t}$ hitung sebesar 0,650 sedangkan $t$ tabel sebesar 2,024 maka $t$ hitung $<\mathrm{t}$ tabel maka Ha ditolak dan Ho diterima, atau dengan melihat tingkat signifikansi yaitu sebesar 0,521, maka rasio aktivitas tidak berpengaruh signifikan terhadap pertumbuhan laba pada perusahaan yang terdaftar di BEI. Dengan demikian hipotesis ketiga yang menyatakan bahwa rasio aktivitas berpengaruhpositif terhadap pertumbuhan laba tidak dapat diterima karena menunjukkan bahwa nilai signifikansi sebesar 0,497 dan nilai ini berada di atas 0,05 yang artinya tidak ada pengaruh yang signifikan antara 
TATO terhadap pertumbuhan laba. Maka dengan demikian bahwa pada kategori perusahaan tekstil dan garmen yang terdaftar di BEI, rasio TATO tidak menunjukkan adanya pengaruh terhadap pertumbuhan laba baik pengaruh positif maupun negatif. Hal ini dengan alasan bahwa penjualan yang tinggi tidak lantas menghasilkan laba yang tinggi pula mengingat beban pokok pada industri garmen tidak terprediksi karena faktor kompetitor yang sangat banyak dengan persaingan harga yang sangat ketat yang mengakibatkan pembengkakan beban sehingga berdampak pula pada kerugian seperti pada deskripsi data yang menunjukkan banyaknya perusahaan yang mengalami kerugian pada beberapa tahun. Oleh karena itu besarnya nilai TATO tidak berpengaruh terhadap pertumbuhan laba. Hasil penelitian ini didukung oleh Mustarsyidah (2009) yang menyatakan bahwa TATO tidak berpengaruh terhadap pertumbuhan laba namun bertentangan dengan hasil penelitian $\mathrm{Ou}$ (1990), Sari (2007) dan Cahyadi (2013) yang menyatakan bahwa TATO tidak berpengaruh terhadap pertumbuhan laba.

Berdasarkan hasil analisis diperoleh nilai $\mathrm{t}$ hitung sebesar 2,411 sedangkan $t$ tabel sebesar 2,024 maka $t$ hitung $>\mathrm{t}$ tabel maka Ho ditolak dan $\mathrm{Ha}$ diterima, atau dengan melihat tingkat signifikansi yaitu sebesar 0,022, maka rasio profitabilitas berpengaruh signifikan terhadap pertumbuhan laba pada perusahaan tekstil dan garmen yang terdaftar di BEI.Dengan demikian hipotesis keempat yang menyatakan bahwa rasio profitabilitas berpengaruh positif terhadap pertumbuhan laba dapat diterima.

Nilai signifikansi pada tabel output SPSS sebesar 0,012 ada di bawah 0,05 sehingga penelitian ini mendukung hipotesis yang telah diajukan. Ini membuktikan bahwa jika rasio pr ofitabilitas yang diukur dengan NPM tinggi maka pertumbuhan laba pun akan ikut meningkat. Berarti perusahaan tekstil dan garmen yang terdaftar di BEI telah berhasil menggunakan laba yang diperolehnya untuk kemudian digunakan kembali untuk menghasilkan penjualan lagi guna menghasilkan laba.Hasil ini sejalan dengan penelitian Zainuddin dan Jogiyanto (1999), Takarini dan Ekawati (2003),Asyik dan Soelistyo (2000), Juliana dan Sulardi (2003) serta Hapsari (2007) yang menyatakan bahwa NPM berpengaruh terhadap pertumbuhan laba.

Berdasarkan hasil analisis diperoleh nilai $\mathrm{t}$ hitung sebesar 0,105 sedangkan $t$ tabel sebesar 2,024 maka $t$ hitung $<\mathrm{t}$ tabel maka Ho ditolak dan Ha diterima, atau dengan melihat tingkat signifikansi yaitu sebesar 0,917, maka PDB tidak berpengaruh signifikan terhadap pertumbuhan laba pada perusahaan tekstil dan garmen yang terdaftar di BEI. Dengan demikian hipotesis kelima yang menyatakan bahwa PDB berpengaruh positif terhadap pertumbuhan laba tidak dapat diterima, yang artinya peningkatan PDB tidak lantas meningkatkan pertumbuhan laba perusahaan terutama perusahaan tekstil dan garmen yang terdapat di BEI. Sehingga bertentangan dengan hasil penelitian Sinuraya (2012) yang menyatakan bahwa PDB akan meningkatkan profitabilitas perusahaan.

\section{SIMPULAN DAN IMPLIKASI}

Rasio likuiditas yang diukur dengan current aset berpengaruh positif terhadap pertumbuhan laba, yang artinya perusahaan yang mempunyai likuiditas tinggi maka perusahaan akan mempunyai aktivitas operasi tinggi pula sehingga berujung pada makin meningkatnya pertumbuhan laba. Rasio 
solvabilitas yang diukur dengan DER tidak berpengaruh terhadap pertumbuhan laba. Artinya berapapun besarnya rasio DER tidak akan mempengaruhi pertumbuhan laba. Ini berarti hutang sudah menjadi suatu kewajiban dan hal yang lumrah terjadi pada dunia usaha, karena dengan hutang maka kebutuhan perusahaan dalam beroperasi akan terpenuhi, tidak melihat apakah laba meningkat atau turun. Rasio aktivitas yang diukur dengan TATO tidak berpengaruh terhadap pertumbuhan laba. Artinya penjualan yang tinggi tidak lantas menghasilkan laba yang tinggi pula apalagi meningkatkan pertumbuhan laba mengingat beban pokok pada industri garmen tidak terprediksi karena faktor kompetitor yang sangat banyak dengan persaingan harga yang sangat ketat yang mengakibatkan pembengkakan beban sehingga berdampak pula pada kerugian. Rasio profitabilitas yang diukur dengan NPM berpengaruh positif terhadap pertumbuhan laba. Ini membuktikan bahwa jika rasio profitabilitas tinggi maka pertumbuhan laba pun akan ikut meningkat. Berarti perusahaan telah berhasil menggunakan laba yang diperolehnya kemudian digunakan kembali untuk menghasilkan penjualan lagi guna menghasilkan laba Yang terakhir, PDB tidak berpengaruh terhadap pertumbuhan laba yang menunjukkan bahwa pertumbuhan laba lebih dipengaruhi oleh faktor internal perusahaan daripada eksternal.

Hasil penelitian ini diharapkan dapat membuat arahan bagi perusahaan agar dapat memperhatikan mengenai kondisi pertumbuhan laba pada perusahaannya yang setiap tahun masih berfluktuasi dan ini membuktikan bahwa masih kurangnya konsistensi perusahaan dalam mempertahankan tren laba yang terus meningkat. Sehingga perlu dikaji kembali mengenai penyebab terjadinya fluktuasi pertumbuhan laba.

\section{DAFTAR PUSTAKA}

Ang, Robert., 1997, Buku Pintar Pasar Modal Indonesia. Edisi Pertama, Rineka Cipta, Jakarta

Asyik, Nur fadjrih dan Soelistyo. 2000.'Kemampuan Rasio

Keuangan dalam Memprediksi Laba". Jurnal Ekonomi dan Bisnis Indonesia. Vol.15, No.3

Beaver, W.H, 1966. "Finansial Ratio as Predictors of Faolure, Empirical Research in Accounting" Selected Studies, Supplement to Journal of Accounting Research, vol, 4 pp 71-111

Chariri, Anis dan Ghazali, Imam. 2001. Teori Akuntansi. Badan Penerbit Universitas Diponegoro, Semarang

Chiarella C. and Gao S. (2004) "The Value of The S\&P $500-A$ Macro View of The Stock Market Adjustment Process". Global Finance Journal. 15; 171-196

Gujarati, Damodar N. 1995. Basic Econometrics. Singapore: Mc Graw Hill,Inc.

Ghozali, I. 2009. Aplikasi SPSS Cetakan IV . Semarang: BP Universitas Diponegoro.

Hanafi, Mamduh M. dan Abdul Halim, 2007. Analisa Laporan Keuangan. Edisi Ketiga. Yogyakarta: UPP STIM YKPN

Harahap, Sofyan Syafri. 2001. Analisis Kritis Laporan Keuangan. Jakarta: PT. Raja Grafindo Persada.

Hooker, Mark A. (2004) "Macroeconomic Factors and Emerging Market Equity Returns: A Bayesian Model 
Selection Approach".

Emerging Markets Review. 5:379-387

Husnan dan Pudjiastuti. 2004. Dasardasar Manajemen Keuangan. Yogyakarta: BPFE.

Irawati, Dhian Eka. 2012. "Pengaruh Struktur Modal, Pertumbuhan Lab, Ukuran Perusahaan dan Likuiditas terhadap Kualitas Laba". Accounting Analysis Journal. Vol. 1, No. 2

Jang, Lesia, Bambang Sugiarto dan Dergibson Siagian. 2007. Faktor-faktor yang mempengaruhi kualitas laba pada Perusahaan Manufaktur di BEJ. Akuntabilitas. Vol. 6, No. 2. Pp 142-149

Jensen, M. C dan Meckling, WH. 1976. "Theory of the Firm: Managerial Behavior, Agency Cost and Ownership Structure". Journal of Financial Aconomics. Oktober 1976, Vol. 3 No. 4, pp 305360.

Juliana, Roma Uly dan Sulardi. 2003. "Manfaat Rasio Keuangan Dalam Memprediksi Perubahan Laba Perusahaan Manufaktur". Jurnal Bisnis \& Manajemen. Vol. 3. No. 2

Kewal, Suramaya Suci, 2012. Pengaruh Inflasi, Suku Bunga, Kurs dan Pertumbuhan PDB terhadap Indeks Harga saham gabungan. Jurnal Ekonomia, Vol 8, No. 1

Lambert, D.M., Stock, J.R., (2001), Strategic Logistic Manajement, Fourth Edition, Mc Graw Hill, New York - USA

Lusiana Noor, Andriyani. 2008. "Analisis Kegunaan RasioRasio Keuangan Dalam Memprediksi Perubahan Laba (Studi Empiris: Pada Perusahaan Perbankan Yang
Terdaftar Di BEI)".Semarang: Universitas Diponegoro.

Mamduh M. Hanafi dan Abdul Halim, 2003, Analisis Laporan Keuangan, UPP AMP YKPN, Yogyakarta

Marsh, T.A. dan Merton, R.C. 1987. "Dividend Behavior for the Aggregate Stock Market". The Journal of Business, Vol 60, No. 1, pp 1-40

Myer, S. and N. Majluf. 1984. "Corporate Financing And Investment Decision When Firms Have Information Investors Do Not Have". Journal of Finance Economics. Vol. 13, pp. 187-221

Ou, Jane A. 1990. "The Information Content of Nonearnings Accounting Numbers as Earnings Predictors". Journal of Accounting Research. Vol. 2. No. 1. Spring

Penman, S.H. 2003. Financial Statement Analysis and Security Valuation. Second Editon: McGraw Hill

Reksoprayitno, Soediyono, 1991, Analisis Laporan Keuangan: Analisis Rasio, Liberty, Yogyakarta

Sangkyun, Park. 1997. "Rationality of negative Stock Price Responses to Strong Economics Activity". Journal Financial Analyst, Sept/Oct 1997

Sari, Ratna Candra dan Zuhrohtun. 2006. "Keinformatifan Laba di 
Pasar Obligasi dan Saham : Uji Liquidation

Option Hypothesis". Simposium Nasional Akuntansi 9.Padang.

Sartono, Agus R. Drs. M.B.A. 2001. Manajemen Keuangan (Teori dan Aplikasi), Edisi Empat, Yogyakarta

Sari, Yuni Nurmala. 2007. "Pengaruh Rasio Keuangan Terhadap Perubahan Laba PadaPerusahaan Manufaktur Yang Terdaftar di BEI Sektor Industri Barang Konsumen". Tesis. Universitas Negeri Malang.

Situmorang, Aston L, 2011."Analisis Pengaruh Variabel makroekonomi terhadap Profitabilitas Perusahaan di Bursa Efek Indonesia”. Tesis USU

Slamet, Achmad. 2003. Handout Analisa laporan Keuangan. UNNES Semarang.

Takarini, Nurjanti dan Erni Ekawati, 2003, "Analisis Rasio Keuangan Dalam Memprediksi Perubahan Laba Pada Perusahaan Manufaktur Di Pasar Modal Indonesia”. Ventura. Vol. 6, No. 3, Desember. Pp 253-270

Tong, G. Q., and Green, C. J. 2005. Pecking order or trade-off hypothesis? Evidence on the capital structure of Chinese companies.

Applied

Economics, 37, 2179-2189.

Usman, Bahtiar, 2003, "Analisis Rasio Keuangan dalam Memprediksi Perubahan Laba pada BankBank di Indonesia", Media Riset Bisnis \& Manajemen, Vol 3 No. 1

Van Horne, James C dan John M. Wachowicz Jr. 2009. PrinsipPrinsip Manajemen Keuangan. Salemba Empat: Jakarta

Warsidi dan Bambang Agus Pramuka.2000. "Evaluasi Kegunaan Rasio Keuangan dalam Memprediksi Perubahan Laba di Masa yang Akan Datang". Jurnal Akuntansi, Manajemen dan Ekonomi.Vol. 2, no. 1, 2000.

Weston, J. Fred. dan Eugene, F. Brigham. 1995. Manajemen Keuangan. Jakarta: Erlangga

Zainudin dan Jogiyanto Hartono. 1999. "Manfaat Rasio Keuangan dalam Memprediksi Pertumbuhan Laba". Jurnal Riset Akuntansi Indonesia

Zhang, G. "Accounting Information, Capital Investment Decisions, and Equity Valuation: Theory and Empirical Implications". Journal of Accounting Research 38 (Autumn 2000): 271-295. 